\title{
Dampak Game Online Pubg terhadap Perilaku Prokrastinasi Siswa
}

\author{
Rezy Safitri ${ }^{*}$, Veryliana Purnamasari², Husni Wakhyudin ${ }^{3}$
}

${ }^{123}$ Program Studi Pendidikan Guru Sekolah Dasar, FIP, Upgris, Semarang, Indonesia

\author{
A R T I C L E I N F O \\ Article history: \\ Received 19 January 2020 \\ Received in revised form \\ 10 February 2020 \\ Accepted 12 March 2020 \\ Available online 25 April \\ 2020 \\ Kata Kunci: \\ Game Online PUBG, Perilaku \\ Prokrastinasi. \\ Keywords: \\ PUBG Online Gaming, \\ Procrastination Behaviou
}

\begin{abstract}
A B S T R A K
Konteks penelitian yang melatar belakangi penelitian adalah banyaknya siswa yang bermain game online PUBG sehingga menyebabkan malas belajar serta menunda-nunda tugas yang diberikan guru. Pengaruh yang ditimbulkan yaitu hasil belajar siswa yang tidak mencapai KKM. Penelitian dilakukan kepada siswa SDN 01 Wiroditan yang bermain PUBG yang terdiri dari kelas IV,V,V1. Permasalahan yang diungkap pada penelitian ini adalah bagaimanakah dampak game online PUBG terhadap perilaku prokrastinasi siswa SDN 01 Wiroditan Bojong Kabupaten Pekalongan. Tujuan penelitian ini adalah untuk mengetahui dampak game online PUBG terhadap perilaku Prokrastinasi siswa SDN 01 Wiroditan Bojong Kabupaten Pekalongan. Sampel penelitian yaitu 38 siswa dan penelitian ini menggunakan metode kualitatif. Pendekatan yang dilakukan dalam penelitian ini adalah deskriptif kualitatif yang dilakukan dengan menguraikan faktafakta dan data-data yang diperoleh dari sumber data. Pengambilan
\end{abstract} data melalui observasi angket, wawancara. Hasil penelitian membuktikan bahwa game online PUBG dapat berdampak pada munculnya perilaku prokrastinasi pada siswa. Hal ini dapat ditunjukkan masih ada beberapa siswa yang sering memainkan game online PUBG dan menunda-nunda tugas dengan sengaja. Oleh karena itu perlu adanya upaya yang dapat dilakukan untuk menekan tingginya perilaku prokrastinasi pada siswa. Kesimpulan dalam penelitian ini adalah permainan game online PUBG berdampak pada perilaku prokrastinasi siswa, antara lain siswa menjadi lupa belajar sehingga tugas sekolah menjadi tertunda dan terbengkalai sehingga dapat menimbulkan perilaku prokrastinasi, masih banyaknya siswa yang mengerjakan tugas secara tidak tepat waktu, banyak siswa yang mengabaikan tugas, serta siswa sering membicarakan game online PUBG dengan temannya.

\section{A B S T R A C T}

The context of the research background is the number of students who play pubg online games, causing lazy learning and delaying the assignment stipulated by the teacher. The research was conducted to students of SDN 01 Wiroditan who play PUBG consisting of grade IV, V,V1. The problem revealed in this study is how pubg online games impact the proclamation behavior of students of SDN 01 Wiroditan Bojong Pekalongan Regency. The purpose of this study is to find out the impact of PUBG online games on the behavior of procistines of students of SDN 01 Wiroditan Bojong Pekalongan Regency. The research sample was 38 students and this study used qualitative methods. The approach taken in this study is qualitative descriptive that is done by deciphering the facts and data obtained from the data source. Data retrieval through poll observation, interview. The results prove that PUBG online gaming can have an impact on the emergence of procritable behavior in students. It can be pointed out there are still some students who often play pubg online games and procrastinate on assignments on purpose. Therefore, there needs to be efforts that can be made to suppress the high proctic behavior in students. The conclusion in this study is that pubg online games have an impact on student pro-procritist behavior, among others students become forgetful of learning so that school work becomes delayed and abandoned so as to cause procritstination behavior, there

\footnotetext{
Corresponding author.

E-mail addresses: rezysft4@gmail.com (Rezy Safitri)
} 
are still many students who do tasks in a timely way, many students who neglect assignments, and students often discuss pubg online games with their friends

Copyright (C) Universitas Pendidikan Ganesha. All rights reserved.

\section{Pendahuluan}

Perkembangan ilmu teknologi sangat berkembang pesat saat ini. Berbagai teknologi dapat kita akses dengan mudah menggunakan internet. Salah satu hasil dari berkembangnya teknologi ialah media bermain anak-anak berbasis internet atau yang biasa disebut dengan game online.

Bermain adalah kehidupan yang dekat dengan anak yang memberikan kesenangan ataupun membangun imajinasi pada anak. Dahulu anak-anak mengenal permainan tradisional yang biasanya dimainkan bersama dengan anak lain-lain seperti congklak dan petak umpet, tetapi pada era sekarang bermain permainan tradisional tidak lagi diminati dan menyenangkan bagi anak- anak usia sekolah dasar. Permainan anak saat ini berubah seiring perkembangan teknologi, anak usia sekolah dasar cenderung menyukai permainan yang mudah dan lebih menarik seperti game online yang terdapat di handphone maupun computer (PC).

Game adalah suatu bentuk permainan. Game online adalah suatu bentuk permainan yang dihubungkan melalui jaringan internet. Menurut Kurniawan (2017 : 98) game online adalah suatu permainan yang dimainkan dikomputer secara online (melalui internet) dan bisa dimainkan oleh banyak orang secara bersamaan. Selanjutnya Suplig $(2017$ : 178) mendefinisikan game online adalah permainan yang berbasis pada jaringan internet di mana para pemain bisa bermain secara online dan dapat diakses oleh banyak orang dan bisa menggunakan perangkat komputer, laptop, smartphone dan tablet. Hal ini juga disampaikan Adams \& Rollings (dalam Putra, 2017 : 3) game online didefinisikan sebagai permainan yang dapat diakses oleh banyak pemain, dimana mesin-mesin yang digunakan pemain dihubungkan oleh suatu jaringan internet. Banyak game online yang dapat diakses dengan jaringan internet melalui komputer, laptop, smartphone, dan tablet.

Salah satu game yang sedang popular saat ini yaitu PlayerUnknown's BattleGrounds (PUBG). Permainan PUBG cenderung membuat penggunanya merasa tertantang dan kecanduan. Fauzi (2019:62) menjelaskan PUBG adalah singkatan dari PlayerUnknown's BattleGrounds yang memuat pertempuran 100 orang secara bersamaan di sebuah area yang besar, yang semuanya datang tanpa perbekalan apapun. PlayerUnknown's Battlegrounds diluncurkan di Steam pada bulan Maret 2017. Pada permainan ini Setiap dari mereka harus memperkuat dan mempersenjatai diri mereka dengan apapun yang mereka temukan di arena yang ada, dari sekedar panci penggorengan untuk senjata melee, boody armor untuk menahan sedikit laju peluru, hingga senjata api kaliber berat. Bisa juga menemukan kendaraan air atau darat untuk ekstra mobilitas. Tidak banyak kesempatan bersembunyi hanya satu tempat saja, karena daerah dimana player bisa bergerak akan terus diperkecil seiring dengan waktu berjalan di sebuah arena besar yang terus memaksa pemain untuk berhadapan langsu.gng dengan satu sama lain.

PUBG merupakan sebuah game multiplayer kompetitif yang bisa dimainkan secara solo atau kelompok dalam format Duo (2 orang) dan juga squad (4 orang), baik secara acak atau dengan mengundang teman dari friend list dengan cara bertahan hidup selama mungkin di arena (Santoso, 2017). Tim yang bertahan hingga akhir, akan memenangkan permainan ini dan mendapatkan point atau disebut "chicken dinner". Permainan ini sangat mudah ditemukan pada playstore yang tersedia di handphone dan permainan ini menggunakan bantuan internet. Permainan ini sangat mudah ditemukan pada playstore yang tersedia di handphone dan permainan ini menggunakan bantuan internet.

Permainan PUBG adalah permainan yang mengasyikan dan menyebabkan kecanduan tersebut dapat berakibat pada intesitas bermain yang tinggi. Hal ini kemungkinan besar akan berdampak pada akademik siswa yaitu perilaku malas belajar dan menunda pengerjaan tugas mereka atau yang dapat disebut dengan perilaku prokrastinasi. Perilaku prokrastinasi akan berdampak besar jika dilakukan terus menerus, salah satu dampaknya yaitu penurunan hasil belajar. Prokrastinasi didefinisikan menurut Ghufron (2012 : 155) sebagai suatu perilaku penundaan yang dilakukan secara sengaja dan berulangulang, dengan melakukan aktivitas lain yang tidak diperlukan dalam pengerjaan tugas. Hal ini juga disampaikan oleh Candra (2014: 67) prokrastinasi akademik adalah penundaan yang dilakukan pada jenis tugas formal yang berhubungan dengan tugas akademik. Penundaan tugas dilakukan dengan sengaja dan sadar oleh setiap individu. Berdasarkan paparan diatas, dapat disimpulkan bahwa prokrastinasi merupakan suatu perilaku yang bertujuan untuk menunda tugas yang berhubungan dengan tugas 
akademik yang dilakukan secara sengaja dan berulang-ulang dan mengganti aktivitas-aktivitas yang tidak penting sehingga tugas tidak dikerjakan.

Berdasarkan hasil observasi awal pada tanggal 2 November 2019 di SDN 01 Wiroditan Bojong Kabupaten Pekalongan ditemukan berbagai fakta dari kelas I, II, III, IV, V, dan VI khususnya kelas IV, V, dan VI antara lain siswa sebagian besar sudah menggunakan handphone dan memainkan game online $P U B G$ saat mereka di rumah setiap hari. Hal ini juga dapat dilihat pada saat jam istirahat banyak dari mereka bercerita mengenai game oline PUBG dan pada saat jam pelajaran terdapat beberapa siswa yang melakukan penundaan tugas yang akhirnya mereka beralasan lupa mengerjakan tugas sehingga dihukum oleh guru. Hal ini juga diperkuat dengan sebagian siswa yang mendapatkan nilai dibawah KKM yaitu 65 dikarenakan bermain game online PUBG yang menyebabkan mereka menunda waktu belajar dan waktu mengerjakan tugas.

Peneliti menggunakan kajian relevan sebagai pendukung penelitian dengan judul "Dampak Game Online PUBG terhadap Perilaku Prokrastinasi Siswa SDN 01 Wiroditan Bojong Kabupaten Pekalongan". Penelitian yang dilakukan Fauzi (2019) menjelaskan bahwa tujuan dari penelitian yang dilakukan yaitu untuk mengetahui adanya pengaruh bermain game online PUBG. Hasil penelitian menunjukkan bahwa terdapat pengaruh game online PUBG terhadap prestasi belajar siswa seperti bermalas-malasan dan mendapatkan nilai rendah. Sutikno (2020) pada penelitiannya mengatakan adapun tujuan penelitiannya yaitu untuk mengetahui hubungan dari pengaruh game online PUBG yang dimainkan oleh para mahasiswa terhkecaadap indeks nilai kumulatif mahasiswa tersebut. Hasil penelitian menunjukkan bahwa terdapat pengaruh terhadap mahasiswa pemain aktif game online PUBG sebesar 82\%. Selanjutnya Ibrena (2019) pada penelitiannya mengatakan tujuan dari penelitiannya adalah untuk mengetahui adakah pengaruh kecanduan game online terhadap perilaku hubungan social remaja di Kota Jakarta. Hasil penelitian menunjukkan bahwa kecanduan game online PUBG memberikan pengaruh sebesar $48 \%$ terhadap perilaku hubungan social remaja di Kota Jakarta. Hal ini dapat disimpulkan bahwa game online PUBG memberikan pengaruh yang positif dan signifikan terhadap perilaku hubungan sosial remaja di Kota Jakarta.

Berdasarkan uraian latar belakang diatas, penulis akan melakukan penelitian lebih dalam mengenai dampak game online terhadap siswa SDN 01 Wiroditan Bojong Kabupaten Pekalongan dengan judul " Dampak Game Online PUBG terhadap Perilaku Prokrastinasi siswa SDN 01 Wiroditan Bojong Kabupaten Pekalongan". Penelitian ini bertujuan untuk mengetahui Dampak Game Online PUBG terhadap Perilaku Prokrastinasi siswa SDN 01 Wiroditan Bojong Kabupaten Pekalongan.

\section{Metode}

Penelitian ini merupakan jenis penelitian kualitatif dengan menggunakan pendekatan deskriptif. Peneliti mendeskripsikan dampak game online PUBG terhadap perilaku prokrastinasi di SDN 01 Wiroditan Bojong Kabupaten Pekalongan dalam bentuk naratif dan sesuai dengan keadaan sesungguhnya. Moleong (2017:6) menjelaskan bahwa penelitian kualitatif adalah penelitian yang bermaksud untuk memahami fenomena tentang apa yang dialami oleh subjek penelitian misalnya perilaku, persepsi, motivasi, tindakan dll., secara holistic dan dengan cara deskripsi dalam bentuk kata-kata dan bahasa, pada suatu konteks khusus yang alamiah dan dengan memanfaatkan berbagai metode alamiah.

Pada penelitian ini peneliti menggunakan sumber data primer dan data sekunder. Dalam penelitian data primer yaitu yang bermain game online PUBG . Data sekunder dalam penelitian ini yaitu informasi dari guru dan kepala sekolah.. Subjek dalam penelitian di khususkan pada siswa yang bermain game online PUBG yang berjumlah 38 siswa. Teknik pengumpulan data dalam penelitian ini menggunakan observasi, wawancara, angket dan dokumentasi. Observasi yang dilakukan peneliti yaitu observasi terstruktur yang merupakan observasi yang telah dirancang secara sistematis tentang apa yang akan amati, kapan dan dimana tempatnya. Wawancara terstruktur kepada guru dan Kepala Sekolah terkait dengan Dampak game online PUBG terhadap Perilaku. Kuisioner atau angket berupa pertanyaanpertanyaan yang harus dijawab oleh siswa sebagai responden.

Metode analisis data yang digunakan dalam penelitian ini menurut Sugiyono (2016:92) yaitu : (a). reduksi data, yaitu merangkum, memilih hal-hal pokok, memfokuskan pada hal-hal yang penting, dicari tema dan polanya. Dalam penelitian ini, peneliti mereduksi data yang akan menerangkan dampak game online PUBG terhadap perilaku prokrastinasi siswa yang ada di SDN 01 Wiroditan Bojong. Dengan demikian data yang telah direduksi akan memberikan gambaran jelas dan mempermudah peneliti untuk mengumpulkan data. (b). Data Display ( Penyajian Data, dalam penelitian kualitatif, penyajian data bisa dilakukan dalam bentuk uraian singkat, bagan, dan sejenisnya. Yang paling sering digunakan untuk penyajian data dalam penelitian kualitatif adalah dengan teks yang bersifat naratif. Dalam penelitian menyajikan data mengenai dampak game online PUBG terhadap perilaku prokrastinasi siswa yang ada di 
SDN 01 Wiroditan Bojong dalam bentuk uraian singkat. (c). Conclusion Drawing / Verification, setelah disajikan, langkah terakhir adalah penarikan kesimpulan dan verifikasi. Hal pertama yang dilakukan penulis adalah penelitian dilapangan secara langsung dengan melihat proses kegiatan yang dilakukan disekolah, dan berwawancara kepada kepala sekolah dan guru kelas untuk menanyakan langsung tentang dampak game online PUBG terhadap kedisiplinan siswa. Setelah tahap tersebut selesai dilakukan, maka langkah terakhir yaitu penarikan kesimpulan.

Teknik pemeriksaan data yang digunakan dalam penelitian ini adalah triangulasi. Pada penelitian ini teknik triangulasi yang digunakan yaitu triangulasi teknik dan triangulasi sumber. Triangulasi teknik adalah teknik pemeriksaan data yang diperoleh melalui observasi, wawancara, angket/ kuisioner, dokumentasi. Sedangkan triangulasi sumber adalah pemeriksaan data yang diproleh dari beberapa sumber melalui siswa, guru, dan kepala sekolah.

\section{Hasil dan Pembahasan}

Observasi digunakan penulis untuk mengamati suasana dan keadaan yang ada di SDN 01 Wiroditan Bojong Kabupaten Pekalongan. Observasi dilakukan pada kondisi awal dan saat penelitian, untuk sasarannya yaitu apa saja dampak game online PUBG yang dapat mempengaruhi perilaku prokrastinasi saat di sekolah. Berdasarkan hasil observasi yang dilakukan, peneliti mendapatkan hasil berupa siswa memainkan game online PUBG saat dirumah dikarenakan ketika disekolah siswa tidak diperbolehkan membawa handphone didalam lingkungan sekolah dan saat jam pelajaran, fakta lain yang ditemukan peneliti pada saat awal penelitian yaitu beberapa siswa sering membicarakan game online PUBG dengan teman sekolah saat istirahat, dan saat pembelajaran berlangsung juga masih terdapat siswa yang asyik berbicara sendiri dan beberapa siswa kurang fokus terhadap pembelajaran yang diberikan oleh guru, siswa mengerjakan tugas secara mandiri dan berkelompok sesuai perintah guru, siswa mengerjakan tugas yang diberikan guru pada saat pembelajaran berlangsung.

Wawancara dilakukan kepada kepala sekolah dan guru kelas IV dan VI secara online melalui google form untuk memperoleh data mengenai dampak game online PUBG terhadap perilaku prokrastinasi siswa. Adapun hasil wawancara sebagai berikut.

Berdasarkan wawancara yang dilakukan penulis dengan kepala sekolah Bapak Akhmad Zaenal Abidin, S.Pd pada tanggal 19 mei 2020 secara online menggunakan google form. Penulis membagikan google form kepada kepala sekolah. Penulis mengajukan beberapa pertanyaan diantaranya, bagaimana dampak game online PUBG terhadap perilaku prokrastinasi, Bapak Kepala sekolah mengutarakan mengenai dampak yang ditimbulkan dari game online PUBG siswa menjadi lupa waktu belajar dan menyebabkan efek buruk pada kesehatan. Siswa yang lupa waktu belajar bisa menjadi salah satu penyebab perilaku prokrastinasi, karena siswa selalu menunda-nunda waktu belajar sehingga tugas-tugas akademiknya tidak dikerjakan.

Adapun faktor-faktor yang bisa menjadi penyebab perilaku menunda tugas siswa yaitu faktor keluarga, faktor kondisi individu, faktor lingkungan sekitar siswa dan juga faktor psikologi. Beberapa faktor tersebut merupakan ciri-ciri siswa yang melakukan penundaan tugas atau bisa disebut dengan prokrastinasi akademik. Adapun faktor lainnya yaitu karena game online membuat siswa penasaran dan permainan yang ditampilkan sangat menantang sehingga siswa tertarik untuk bermain.

Dari paparan diatas, Bapak Kepala Sekolah memberikan himbauan kepada orang tua untuk membatasi waktu bermain game online pada anaknya sehingga siswa tidak lupa waktu belajar dan mengerjakan tugas, adapun untuk sekolah harusnya guru kelas dapat memberikan sosialisasi terhadap dampak berbahaya game online.

Berdasarkan wawancara yang dilakukan oleh peneliti kepada wali kelas IV SDN 01 Wiroditan Bojong Kabupaten Pekalongan Ibu Tiya Apriyani, S.Pd. Peneliti mengajukan pertanyaan mengenai bagaimana dampak game online terhadap perilaku prokrastinasi siswa, ibu guru mengutarakan bahwa game online PUBG berpengaruh terhadap perilaku prokrastinasi, hal ini terlihat ketika siswa diberi tugas kemudian masih banyak yang tidak mengerjakan dengan tepat waktu, tugas seringkali diabaikan dan siswa memilih untuk selalu bermain game online.

Untuk mengurangi penundaan tugas pada siswa ibu guru memberikan himbauan kepada orang tua agar berperan penting dalam memantau anak dan selalu menanyakan tugas - tugas dari guru, hal ini tentu akan mengurangi penundaan tugas pada siswa, terlebih jika orangtua mau membimbing, mengarahkan dan menemani anak ketika ada tugas yang diberikan kepada anak. Adapun peram guru dalam mengurangi dampak game online terhadap siswa yaitu dengan berupa pengarahan kepada siswa terkait dampak seringnya bermain game online, memberikan pandangan dan bimbingan untuk masa depan para siswa. 


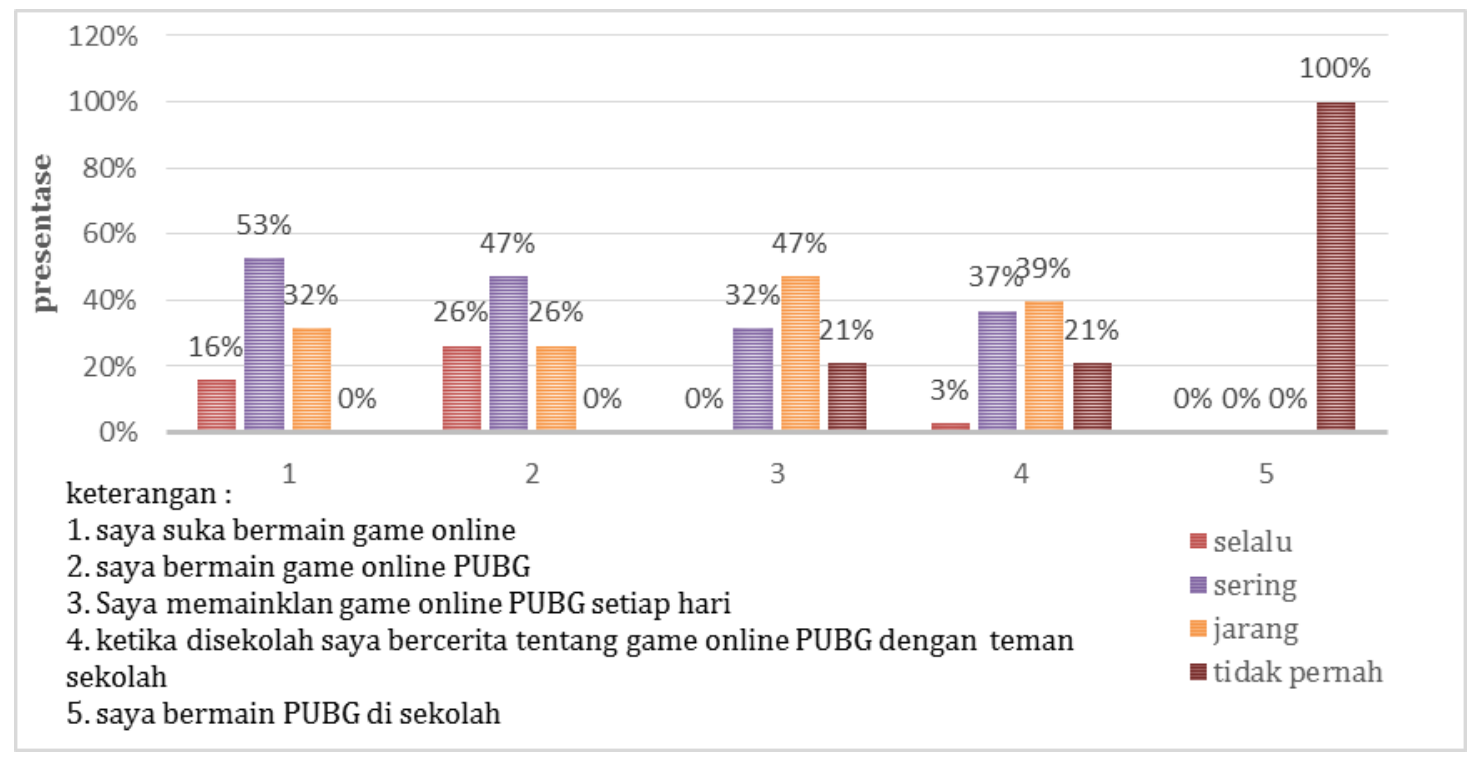

Gambar1. Hasil Angket/Kuisioner Pernyataan No. 1-5

Dari Gambar 1 diperoleh hasil angket dari pernyataan 1-5. Pernyataan 1 saya selalu suka bermain game online, diperoleh hasil tertinggi 53\% menyatakan sering suka bermain game online. Pernyataan 2 saya suka bermain game online PUBG, diperoleh diperoleh hasil tertinggi $47 \%$ yang menyatakan sering bermain game online PUBG. Pernyataan 3 Saya memainkan game online PUBG setiap hari, diperoleh hasil tertinggi $47 \%$ menyatakan jarang memainkan game online PUBG setiap hari. Pernyataan 4 Ketika di sekolah saya bercerita tentang game online PUBG dengan teman sekolah, hasil tertinggi diperoleh $39 \%$ jarang ketika disekolah bercerita game online PUBG dengan teman sekolah Pernyataan 5 Saya bermain PUBG di sekolah, diperoleh 100\% tidak pernah bermain PUBG di sekolah

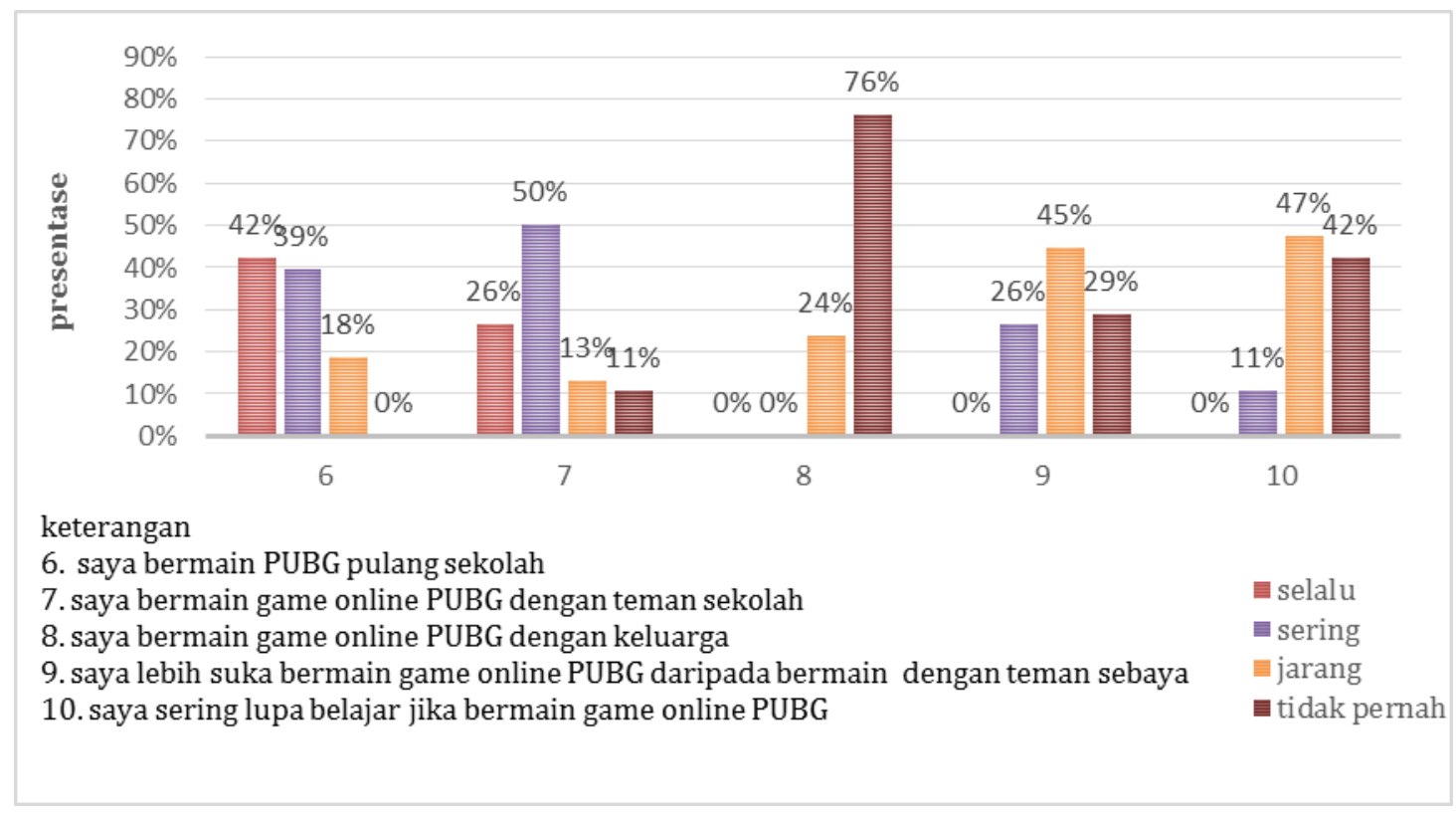

Gambar 2. Hasil Angket/Kuisioner Pernyataan No. 6-10

Berdasarkan Gambar 2 diperoleh hasil angket/kuisioner siswa dari penyataan nomor 6-10. Pernyataan 6 Saya bermain PUBG sepulang sekolah, diperoleh hasil tertinggi 42\% selalu bermain PUBG sepulang sekolah. Pernyataan 7 Saya bermain game online PUBG dengan teman sekolah, diperoleh hasil tertinggi 50\% menyatakan sering bermain game online PUBG dengan teman sekolah. Pernyataan 8 Saya bermain game online PUBG dengan keluarga, hasil tertinggi diperoleh $76 \%$ menyatakan tidak pernah bermain game online PUBG dengan keluarga. Pernyataan 9 Saya lebih suka bermain game online PUBG 
daripada bermain dengan teman sebaya. Pernyataan 10 Saya sering lupa belajar jika bermain game online PUBG, diperoleh hasil terendah yaitu 47\% menyatakan jarang lupa belajar jika bermain game online.

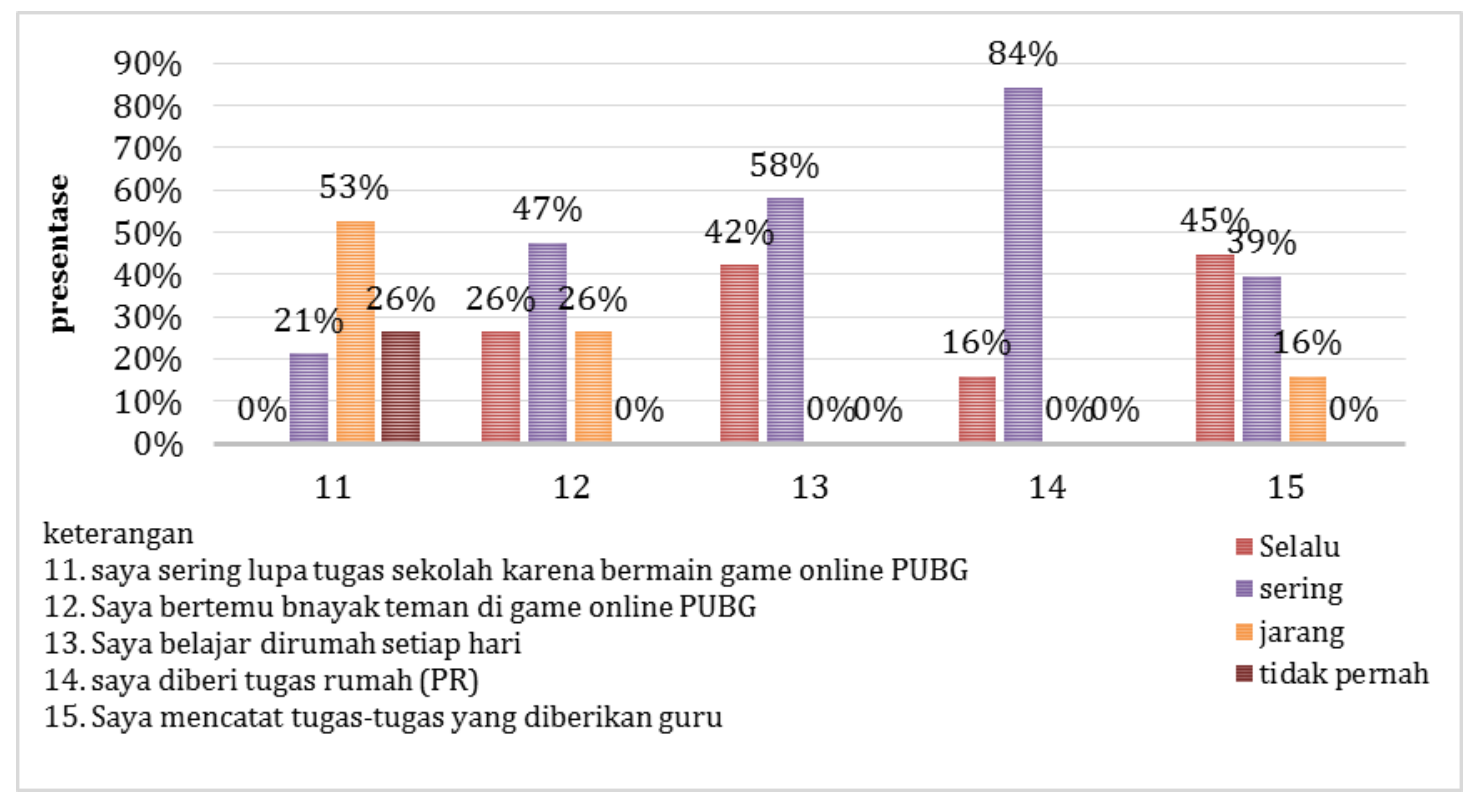

Gambar 3. Hasil Angket/Kuisioner Pernyataan No. 11-15

Berdasarkan Gambar 3 diperoleh hasil angket siswa dari pernyataan nomor 11-15. Pernyataan 11 Saya sering lupa tugas sekolah karena bermain game online PUBG, diperoleh hasil tertinggi 53\% menyatakan jarang lupa tugas sekolah karena bermain game online. Pernyataan 12 Saya bertemu banyak teman di game online PUBG, diperoleh hasil tertinggi yaitu 47\% menyatakan sering bertemu banyak teman di game online PUBG. Pernyataan 13 Saya belajar dirumah setiap hari, diperoleh hasil tertinggi yaitu 58\% menyatakan seting belajar dirumah setiap hari. Pernyataan 14 Saya diberi tugas rumah (PR) oleh guru, diperoleh hasil tertinggi yaitu $84 \%$ menyatakan sering diberi tugas rumah (PR). Pernyataan 15 Saya mencatat tugas-tugas yang diberikan guru, diperoleh hasil tertinggi yaitu $43 \%$ selalu mencatat tugastugas yang diberikan guru.

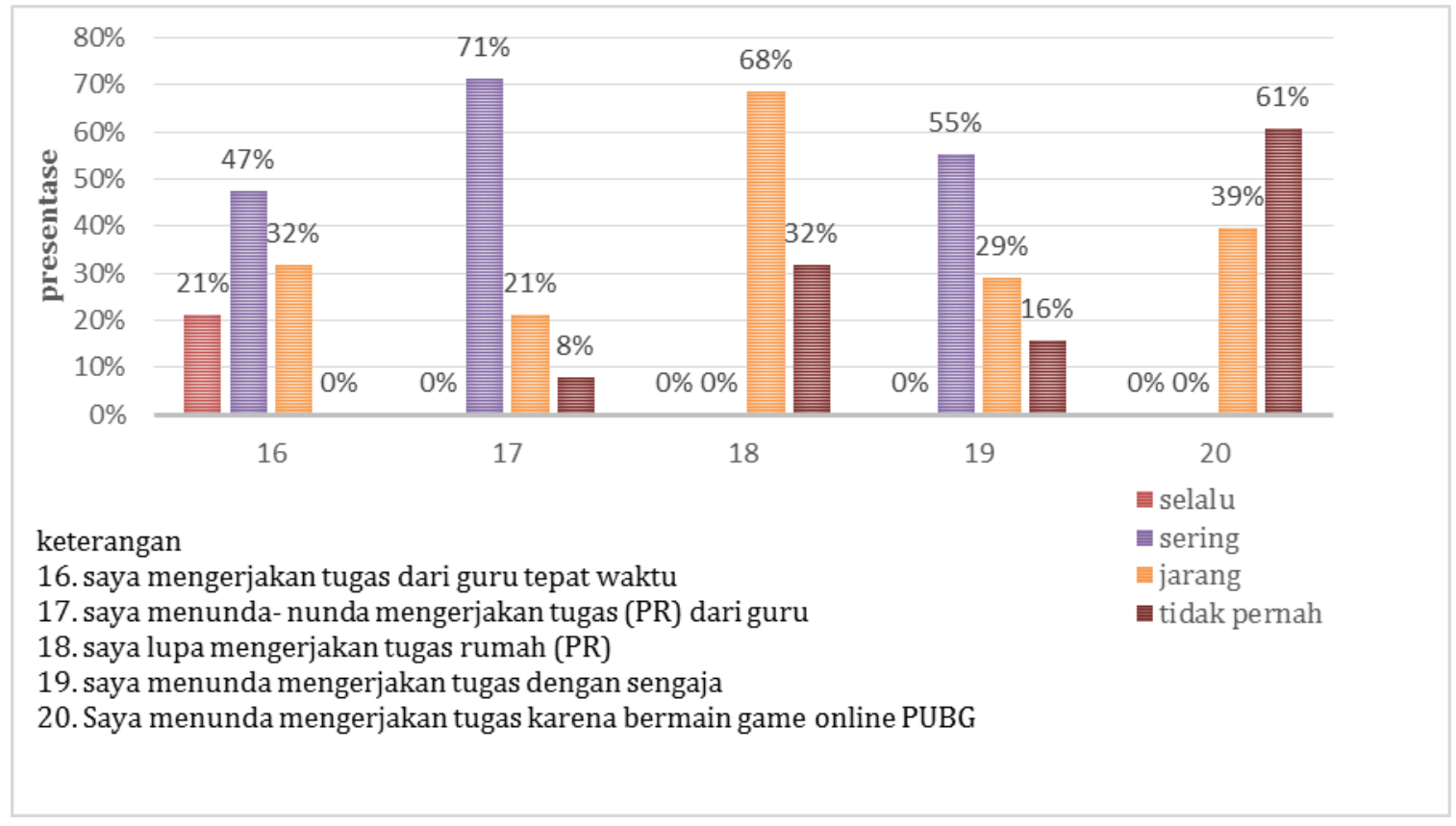

Gambar 4. Hasil Angket/Kuisioner Pernyataan No. 1-5 
Dari Gambar 4 diperoleh hasil angket siswa dari pernyataan nomor 16-20. Pernyataan 16 Saya mengerjakan tugas dari guru tepat waktu, diperoleh hasil tertinggi $47 \%$ menyatakan sering mengerjakan tugas dari guru tepat waktu. Pernyataan 17 Saya menunda-nunda mengerjakan tugas (PR) dari guru, diperoleh hasil tertinggi 71\% menyatakan sering menunda-nunda mengerjakan tugas (PR). Pernyataan 18 Saya lupa mengerjakan tugas rumah (PR), diperoleh hasil tertinggi 68\% menyatakan jarang lupa mengerjakan tugas rumah (PR)). Pernyataan 19 Saya menunda mengerjakan tugas dengan sengaja, diperoleh hasil tertinggi 55\% menyatakan sering menunda mengerjakan tugas dengan sengaja. Pernyataan 20 Saya menunda mengerjakan tugas karena bermain game online PUBG, diperoleh hasil tertinggi 61\% menyatakan tidak pernah menunda mengerjakan tugas karena bermain game online PUBG

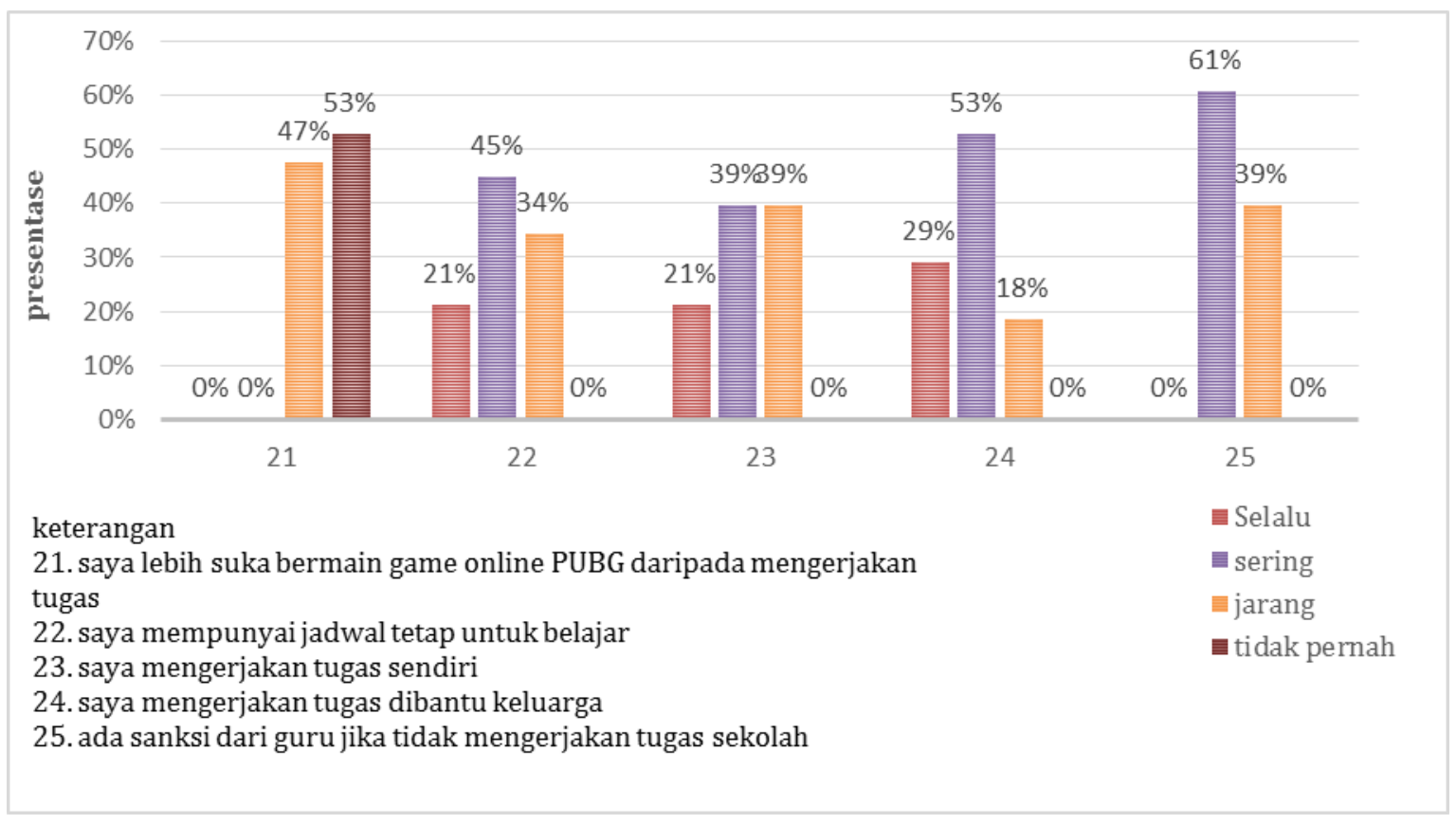

Gambar 5. Hasil Angket/Kuisioner Pernyataan No. 21-22

Dari Gambar 5 diperoleh hasil angket siswa dari peryataan nomor 21-25. Pernyataan 21 Saya lebih suka bermain game online daripada mengerjakan tugas, diperoleh hasil tertinggi 53\% tidak pernah lebih suka bermain game online daripada mengerjakan tugas. Pernyataan 22 Saya mempunyai jadwal tetap untuk belajar, hasil tertinggi $45 \%$ menyatakan sering mempunyai jadwal tetap untuk belajar. Pernyataan 23 Saya mengerjakan tugas sendiri, diperoleh hasil tertinggi 39\% menyatakan sering mengerjakan tugas sendiri dan menyatakan jarang mengerjakan tugas sendiri. Pernyataan 24 Saya mengerjakan tugas dibantu keluarga, diperoleh hasil tertinggi 53\% menyatakan sering mengerjakan tugas dibantu keluarga.. Pernyataan 25 Ada sanksi dari guru jika tidak mengerjakan tugas sekolah, diperoleh hasil tertinggi 62\% menyatakan sering ada sanksi dari guru jika tidak mengerjakan tugas sekolah.

Berdasarkan deskripsi data hasil penelitian yang telah terkumpul, maka langkah selanjutnya adalah pembahasan dari hasil penelitian tentang dampak game online PUBG terhadap perilaku prokrastinasi siswa SDN 01 Wiroditan Bojong Kabupaten Pekalongan. Berdasarkan hasil observasi yang dilakukan peneliti terdapat siswa yang bermain game online PUBG di SDN 01 Wiroditan terdiri dari kelas IV, V, dan VI. Pada kelas rendah I, II, III tidak terdapat siswa yang memainkan game online PUBG, dikarenakan siswa kelas rendah belum diperbolehkan menggunakan Handphone oleh orang tua dan belum mengetahui cara bermain game online PUBG. Hal tersebut diperkuat oleh hasil angket yang diberikan kepada siswa yang menyatakan siswa yang bermain game online PUBG terdiri dari kelas IV, V, VI yang rata-rata dari mereka sudah diperbolehkan menggunakan Handphone dan sudah tahu cara bermain game online PUBG. Dalam observasi yang dilakukan peneliti pada tahap awal, peneliti menemukan fakta bahwa siswa banyak yang asyik bercerita mengenai permainan game online PUBG yang meliputi strategi menyerangnya lalu bercerita mengenai tim yang dimainkan saat bermain bersama temannya, hal ini didukung dengan hasil angket yang dibagikan kepada siswa juga menunjukkan lebih dari 37\% dari 38 siswa sering bercerita game online PUBG saat di sekolah bersama temannya.. 
Berdasarkan wawancara dengan guru yang bernama Tiya Apriyani, S.Pd dijelaskan bahwa prokrastinasi adalah sikap seseorang menunda pekerjaan, salah satunya adalah menunda tugas. Hal ini sesuai dengan teori Kurniawan (2017 : 98) yang menjelaskan prokrastinasi adalah kebiasaan menunda suatu tugas pekerjaan sampai batas akhir pengumpulan tugas atau pekerjaan tersebut. Berdasarkan hasil wawancara dengan guru dan kepala sekolah dijelaskan siswa yang melakukan prokrastinasi dapat disebabkan beberapa faktor. Adapun faktor yang mempengaruhi yaitu meliputi kondisi fisik individu, ketika siswa yang kondisi fisiknya capek atau kurang fit akan membuat siswa menunda-nunda tugas sekolah. Kondisi psikologi individu, dijelaskan bahwa siswa yang kondisi psikologinya baik dan stabil akan cenderung semangat dalam mengerjakan tugas. Gaya pola asuh orang tua, dijelaskan bahwa pola asuh yang cenderung perhatian terhadap anak dalam pendidikan tentu akan meminimalisir prokrastinasi dan sebaliknya jika orang tua kurang peduli akan membuat anak malas dan menunda tugas. Kondisi lingkungan, dijelaskan linkungan yang cenderung mendukung siswa untuk memprioritaskan belajar akan berpengaruh dalam semangat belajar anak dilingkungan tersebut.

Hasil data yang menunjukkan ciri-ciri siswa melakukan perilaku prokrastinasi berdasarkan data pada saat penelitian yaitu terdapat penundaan untuk memulai dan menyelesaikan tugas, dalam hal ini dapat diketahui melalui angket yang dibagikan siswa terdapat $71 \%$ siswa yang sering menunda-nunda tugas dengan sengaja dan melakukan aktivitas yang tidak penting. Keterlambatan dalam mengerjakan tugas, menurut hasil penelitian yang dilakukan melalui angket siswa dan wawancara dengan guru terdapat masih seringnya beberapa siswa yang tidak mengerjakan tugas secara tepat waktu, hal ini dikarenakan biasanya siswa lebih senang bermain atau beralasan tidak paham dengan soal yang diberikan guru. Kesenjangan waktu antara rencana dan kinerja intelektual, banyak dari siswa yang masih banyak menunda-nunda tugas secara sengaja dikarenakan siswa tidak bisa membagi waktu untuk belajar dan bermain sehinggga terjadi kesenjangan, hal ini dapat terlihat dari angket yang diberikan terhadap siswa. Melakukan aktivitas yang lebih menyenangkan, dalam hal ini banyak siswa yang melakukan penundaan tugas dikarenakan mereka biasanya bermain game online PUBG sampai akhirnya mereka lupa waktu dan tidak mengerjakan tugasnya. Penjabaran tersebut sesuai dengan teori Ferrari dkk, 1995 (dalam Ghufron 2012:158) yang menyatakan ciri-ciri seseorang yang melakukan prokrastinasi yaitu penundaan untuk memulai dan menyelesaikan tugas, keterlambatan dalam mengerjakan tugas, kesenjangan waktu antara rencana dan kinerja intelektual, melakukan aktivitas yang lebih menyenangkan.

Berdasarkan uraian diatas, maka penlitian ini dapat membuktikan bahwa game online PUBG dapat berdampak pada munculnya perilaku prokrastinasi pada siswa. Hal ini dapat ditunjukkan masih ada beberapa siswa yang sering memainkan game online PUBG dan menunda-nunda tugas dengan sengaja. Oleh karena itu perlu adanya upaya yang dapat dilakukan untuk menekan tingginya perilaku prokrastinasi pada siswa. Salah satunya yang dapat dilakukan yaitu dengan mengurangi intensitas bermain game online serta peran penting guru dan orang tua yang harus memberikan bimbingan dan sosialisasi.

\section{Simpulan dan Saran}

Dari hasil penelitian yang dilakukan di SDN 01 Wiroditan Bojong Kabupaten Pekalongan mengenai "Bagaimana dampak game online $P U B G$ terhadap perilaku prokrastinasi siswa SDN 01 Wiroditan Bojong Kabupaten Pekalongan?" dapat disimpulkan bahwa permainan game online PUBG berdampak pada perilaku prokrastinasi siswa, antara lain siswa menjadi lupa belajar sehingga tugas sekolah menjadi tertunda dan terbengkalai sehingga dapat menimbulkan perilaku prokrastinasi, masih banyaknya siswa yang mengerjakan tugas secara tidak tepat waktu, banyak siswa yang mengabaikan tugas, serta siswa sering membicarakan game online PUBG dengan temannya. Adapun dampak lainnya siswa menjadi kurang fokus pada saat pembelajaran berlangsung. Cara yang dilakukan guru pada saat siswa tidak mengerjakan tugas, guru akan memberikan teguran dan menanyakan mengapa tidak mengerjakan tugas kemudian anak diberikan lagi batasan waktu untuk mengerjakan tugasnya serta diberikan hukuman untuk memberikan efek jera pada siswa sehingga siswa menjadi disiplin dalam mengerjakan tugas dan mengikuti pembelajaran guru.

Dari hasil analisis serta kesimpulan penelitian yang dilakukan di SD N 01 Wiroditan Bojong Kabupaten Pekalongan, saran yang dapat dikemukakan peneliti yaitu: Bagi orang tua selalu dampingi anak saat bermain game online dan berikan batasan waktu anak untuk bermain game online agar anak punya tanggung jawab, Bagi sekolah hendaknya berikan sosialisasi mengenai dampak-dampak game online agar siswa tahu dan mengerti sehingga siswa tidak menjadi kecanduan dengan game online, Bagi siswa diharapkan lebih meningkatkan belajar dan membatasi diri dalam bermain game online. 


\section{Daftar Rujukan}

Ali, Imam. Daftar Senjata PUBG Mobile, lengkap dengan spesifikasinya. https://www.pricebook.co.id/article/game_apps/2018/04/10/8248/daftar-lengkap senjatapubg-mobile . diakses 2 maret 2020.

Candra, Ujang, dkk. 2014. Faktor-faktor Penyebab Prokrastinasi Akademik Pada Siswa Kelas XI SMA Negeri Kabupaten Temanggung. Indonesian Journal Guidance and Counseling. Vol 3, No.3.

Fauzi, Ach. 2019. Pengaruh Game Online Pubg (Player Unknown's Battle Ground) Terhadap Prestasi Belajar Peserta Didik. Jurnal SciensEdu. : Vol. II. No. 1 June 2019

Ghufron, M. Nur, dan Rini Risnawati S. 2012. Teori-Teori Psikologi. Jogjakarta : Ar RuzzMedia

Ibrena, Regyna Eninta, Dan Ratih Hasanah Sudrajat. “Pengaruh Kecanduan Game Playerunknown's Battleground (PUBG) Terhadap Perilaku Hubungan Social Remaja Di Kota Jakarta". Jurnal eProceeding of Management. Vol.6, No. 3, 2019

Kurniawan, Drajat Edy. 2017. Pengaruh Intensitas Bermain Game Online Terhadap Perilaku Prokrastinasi Akademik Pada Mahasiswa Bimbingan Dan Konseling Universitas Pgri Yogyakarta. Jurnal Konseling GUSJIGANG: Vol. 3 No. 1

Masya, Hardiansyah, dan Dian Adi Candra. 2016. Faktor-Faktor Yang Mempengaruhi Perilaku Gangguan Kecanduan Game Online Pada Peserta Didik Kelas X Di Madrasah Aliyah Al Furqon Prabumulih Tahun Pelajaran 2015/2016. Jurnal Bimbingan dan Konseling Vol.3 No.1 (2016)

Moleong, Lexy J. 2017. Metodologi Penelitian Kualitatif. Bandung: PT Remaja Rosdakrya. Edisi Revisi.

Santoso, Pladidus. 2017. Review Playerunknown's (PUBG):Popularitas Sepadan! http://jagatplay.com/2017/12/pc-2/review-playerunknowns-battlegrounds-pubg popularitas sepadan/. Diakses 2 Januari 2020.

Septiyani, Amalia. 2019. Ini Panduan Lengkap Bermain PUBG Mobile Untuk Pemula Alias Newbie. https://games.grid.id/read/151727131/ini-panduan-lengkap-bermain-pubg-mobile-untukpemula-alias-newbie?page=all. Diakses 1 Maret 2019

Setiawan, Heri Satria. 2018. Analisis Dampak Pengaruh Game Mobile Terhadap Aktifitas Pergaulan Siswa Sdn Tanjung Barat 07 Jakarta. Jurnal Faktor Extra. Vol. 11 No.2

Sugiyono. 2017. Metodologi Penelitian Pendidikan Pendekatan Kuantitatif, kualitatif dan RnD. Bandung : Alfabeta

Sugiyono. 2016. Memahami Penelitian Kualitatif. Bandung : Alfabeta

Suplig, Maurice Andrew. 2017. Pengaruh Kecanduan Game Online Siswa SMA Kelas X Terhadap Kecerdasan Sosial Sekolah Kristen Swasta Di Makassar. JURNAL JAFFRAY. Vol.15 No. 2

Sutikno, Arif, Dan Yudhistiro Pandu W. 2019. “Pengaruh Game Online Pubg Terhadap Indeks Prestasi Belajar Mahasiswa Pti Unisri". Research Fair Unisri. Vol. 4, No.1 